\title{
The Impact Of Geographic Location, Industry Type, Number Of Employees And Years In Business On The Economic Success Of Minority Women Entrepreneurs \\ Andrea E. Smith-Hunter, (Email: ahunter@siena.edu), Siena College William Engelhardt, (Email: engelhardt@siena.edu), Siena College Gilbert Brookins, (Email: Brookins@siena.edu), Siena College
}

\begin{abstract}
The topic of entrepreneurship is central in both scholarly and public policy discussions of minority businesses, yet few studies have examined the factors leading to economic success for minority women entrepreneurs. This paper partially addresses the oversight by analyzing Dun and Bradstreet data on businesses owned by Asian, Hispanic, Native American, Indian and Black women, focusing on the relationship between sales volume (the dependent variable) and number of employees, years in business, race and industry type (the independent variables). The results from this paper add a new dimension to this line of research, building on previous studies that document the growing significance of entrepreneurship among minority women. The results show that there is indeed an impact on sales volume by number of employees, years in business, race and industry type.
\end{abstract}

\section{INTRODUCTION AND LITERATURE REVIEW}

6 ne of the strongest arguments for promoting minority enterprises is that such businesses provide their owners with an escape route from discrimination and lack of upward mobility denied them in the mainstream labor market (Wilson and Portes, 1980; Zhou and Logan, 1989; Haddleston-Mattai, 1995). It has been widely acknowledged that minority owned enterprises are often small and undercapitalized and might provide little opportunity for employment of others or socioeconomic advancement of their owners (Brimmer and Terrell, 1971; Bates, 1997; Sanders and Nee, 1987). Nonetheless, small businesses do create the majority of new jobs in an economy (Birch, 1987) and their impact on the advancement of any country's economy cannot be denied (Maysami and Goby, 1999). With this in mind, it is reasonable to surmise that a look at the factors leading to the economic success of minority women enterprises deserve a special focus in the realm of the entrepreneurship literature.

This paper and its resulting focus can, in a modest way, be a benefit to the literature on women, minority women, entrepreneurship and most notably, minority women entrepreneurs. The factors impacting the economic success of women entrepreneurs takes on a new dimension when one considers the special case of women-owned minority businesses with a focus across racial lines. Minority women are of special importance since their dual dimension has lead to them being considered as occupying a "double-disadvantaged" position in the labor force, owing to the hardships caused by racism and sexism (Smith and Tienda, 1998; Haddleston-Mattai, 1995).

In addition, studies have shown that the number of minority women who own businesses is growing (see Table 1), not only because of their improvements in their human and financial capital positions, but also because of the alternatives these improvements have provided this faction of women. The contribution of minority women to the expansion of the entrepreneurial sector has, accordingly, received widespread attention (Light and Gold, 2000; Smith- 
Hunter, 2003; Inman, 2000). However, despite their rising interests, few studies have examined the factors leading to economic success of women-owned minority businesses. In addition, almost none of these studies have done so with an emphasis across racial strata. This oversight is remarkable, since the contribution of minority women entrepreneurs has been a central and dominant topic of research in the entrepreneurship literature for the last fifteen years (Light and Gold, 2000; Smith-Hunter, 2003; Inman, 2000; Maysami and Goby, 1999; Loscocco and Robinson, 1991; Moore and Buttner, 1997).

Overall, the literature on women's business ownership suggests that, in terms of both entrepreneurial options (e.g., occupational choices) and entrepreneurial resources (e.g., sources of capital), women are more disadvantaged than men, and minority women are more disadvantaged than white women. These findings are, of course, well known. However, they are rarely scrutinized with a cross-comparative focus across racial lines for women only. Moreover, relatively few studies have examined racial differences in women's business ownership by investigating, for example, possible differences in the industry type of minority women business owners and the impact of this on economic success.

A few of the studies to look specifically at economic success among women business owners were undertaken by Loscocco and Leicht (1993) and Loscocco et al (1991). Loscocco and Leicht (1993) conducted a telephone survey of men and women who owned health service businesses, eating and drinking establishments, and computer sales and software companies in 12 Indiana counties. The study looked at economic success factors such as gross receipts of the business, as well as owners' earnings received from the business. The results showed gender similarity in the processes through which earnings were determined, although there were differences in many of the predictor variables (Loscocco and Leicht, 1993). In addition, while there were differences in female versus male business owners, the gender discrepancies in sales volume and earnings among the business owners was not seen as particularly wide (Loscocco and Leicht, 1993).

The study by Loscocco et al (1991) looked at the financial success of female and male small business owners. The data came from a pilot study of small businesses in the New England area, with information collected from mailed questionnaires. The authors concluded that the relatively small size of women owned businesses was the major factor explaining their financial disadvantage, when compared to their male counterparts (Loscocco et al, 1991). In addition, the authors concluded that the lack of experience and their concentration in less profitable industries also contributed to the women's unfavorable financial position (Loscocco et al, 1991). The factors leading to the success of women business owners on an international level are presented in Table 3 on page 6.

Another area of interest when analyzing the economic returns for women entrepreneurs is that of home based businesses. The general consensus is that women in home-based businesses tend to earn lower economic returns when compared to other groups (Becker and Moen, 1999; Edwards and Field-Hendrey, 1996; Furry, 1992). This phenomenon can partly be explained by three key reasons. The first reason is the types of industries in which women tend to be involved. Women home-based owners are more likely to operate businesses that are seen as a hobby or an extension of their gendered roles as homemakers compared to their counterparts who locate outside of the home. Such gendered types of businesses have been referred to as "pink collar" businesses by some authors (Ehlers and Main, 1998). Such industries often offer lower returns for their participants (Loscocco and Robinson, 1991; Moore and Buttner, 1997; Smith-Hunter, 2003).

The second reason is the lowered number of hours women involved in home based businesses tend to work because of their other commitments (Priestnitz, 1989; Olson, 1997; Edwards and Field-Hendrey, 1996). A third reason that has been advanced for the lowered earnings is the smaller amount of initial capital that women home based business owners have to start a business (Priestnitz, 1989). This latter reason has been used to explain why women are more likely to locate a business in the home in the first place (Priestnitz, 1989). International studies that have assessed factors that have contributed to women business owners' success are summarized in Table 2.

The inroads that minority women entrepreneurs are making into the economy in general, and the small business sector in particular are societal trends that are deserving of scholarly investigation. The goal of this paper is to add to the literature on entrepreneurship by filling the conspicuous gap in knowledge regarding a comparative 
analysis of minority women entrepreneurs. This article answers four main groups of questions. First, what are the relationships between race and number of employees, geographic location of a business, type of business, years in business and sales volume? In a related query, the second question looks at what are the relationships between sales volume and years in business, geographic location, types of business and number of employees? A third question looks at the impact of race, geographic location, industry type, number of employees and years in business (independent variables) on sales volume (a dependent variable). A final question looks at the preceding relationship, holding race constant.

To answer these questions, we examine data, collected by Dun and Bradstreet, on women-owned minority businesses, studying those establishments that have positive values for net worth and are classified as Asian-, Hispanic- or Black-owned. These data provide valuable information on the attributes of women-owned minority businesses that cannot be obtained from other sources, such as the U.S. Bureau of the Census. The focus on Asian, Hispanics, Native Americans, Indians and Blacks reflects the traditional concern of the literature on ethnic enterprises with the various minority groups of the American society.

\section{DATA AND ANALYSES}

One of the most reputable database firms in the United States, Dun and Bradstreet obtains information from millions of public and private businesses - many of which volunteer to be surveyed - as well as from trade tapes, trade associations, court records, government documents, inter-business publications, banks and other financial institutions. In the present study, Dun and Bradstreet (2003) data were used to build a sample frame that was stratified by geographic region, gender, industry (using the Standard Industry Code), sales volume, number of employees and number of years in businesses. The enterprises included in this frame were located mainly in those cities with the 10 largest populations of women-owned businesses, based on the U.S. Census of 2000, namely: New York, Los Angeles, Chicago, Houston, San Diego, Dallas, San Francisco, Phoenix, San Antonio, and Seattle, with additional data from a few others. In building the sample frame, no restrictions were placed on annual financial figures or number of employees. However, to be included, the businesses had to have been in existence for at least a year.

\section{DESCRIPTIVE STATISTICS}

Table 3, 4 and 5 shows the descriptive statistics. Several findings are worthy of note.

- $\quad$ Businesses owned by Native Americans $(n=66)$ have the highest figures for the sales volume, average employees per business and average years in business (see Table 3 ).

- $\quad$ Most of the women businesses are found in the services industry, followed by retail trade, regardless of the racial strata one looks at (see Table 4).

- Native Americans have the highest percentage of concentrations in the construction, manufacturing and the transportation, communications and public utilities industries compared to the other four racial groups (see Table 4).

- $\quad$ The top three majority States for Hispanics are California, Florida and Texas. For Blacks the top three States are Texas, California and Georgia. For Asians, the top three States are California, New York and Texas. For Indians the top three States are California, New York and Illinois and for Native Americans the top three States are California, Texas and Arizona (see Table 5).

\section{CHI-SQUARE RESULTS}

Table 6 represents the chi-square values for the relationship between race and other variables. There was a significant $(\mathrm{p}=0.00)$ relationship found between race and the following: geographic location, type of business and sales volume. The two relationships that were found not to be significant were race and number of years in business and race and number of employees. Alternatively, Table 7 indicates that there were significant results $(\mathrm{p}=0.00)$ found between sales volume and the following: geographic location, years in business, type of business and number of employees. 
TABLE 1 - Minority-Owned Firms In The United States: 2002

\begin{tabular}{|c|c|c|c|c|}
\hline & $\begin{array}{c}\text { Minority } \\
\text { Women-Owned } \\
\text { Firms } \\
\end{array}$ & $\begin{array}{l}\text { All Minority } \\
\text { Owned Firms }\end{array}$ & $\begin{array}{l}\text { \% Change } \\
\text { 1997-2002 }\end{array}$ & $\begin{array}{c}\text { Share of All } \\
\text { Firms }\end{array}$ \\
\hline $\begin{array}{l}\text { All Minorities: } \\
\text { Number of Firms } \\
\text { Employment } \\
\text { Sales }(\$ 000) \\
\end{array}$ & $\begin{array}{c}1,214,309 \\
822,357 \\
\$ 100,571,001 \\
\end{array}$ & $\begin{array}{c}3,941,536 \\
6,223,536 \\
\$ 945,110,859 \\
\end{array}$ & $\begin{array}{c}31.5 \\
5.7 \\
18.8 \\
\end{array}$ & $\begin{array}{l}30.8 \\
13.2 \\
10.6 \\
\end{array}$ \\
\hline $\begin{array}{l}\text { African American: } \\
\text { Number of Firms } \\
\text { Employment } \\
\text { Sales }(\$ 000)\end{array}$ & $\begin{array}{c}365,110 \\
197,151 \\
\$ 14,485,453 \\
\end{array}$ & $\begin{array}{c}1,035,514 \\
787,332 \\
\$ 94,379,957 \\
\end{array}$ & $\begin{array}{c}16.7 \\
16.6 \\
6.9 \\
\end{array}$ & $\begin{array}{l}35.3 \\
25.0 \\
15.3 \\
\end{array}$ \\
\hline $\begin{array}{l}\text { Asian \& Pacific Islander: } \\
\text { Number of Firms } \\
\text { Employment } \\
\text { Sales }(\$ 000) \\
\end{array}$ & $\begin{array}{c}358,503 \\
370,101 \\
\$ 49,069,703 \\
\end{array}$ & $\begin{array}{c}1,258,806 \\
3,654,527 \\
\$ 543,079,183 \\
\end{array}$ & $\begin{array}{l}44.6 \\
18.0 \\
28.8 \\
\end{array}$ & $\begin{array}{c}28.5 \\
10.1 \\
9.0 \\
\end{array}$ \\
\hline $\begin{array}{l}\text { Hispanic: } \\
\text { Number of Firms } \\
\text { Employment } \\
\text { Sales }(\$ 000) \\
\end{array}$ & $\begin{array}{c}470,344 \\
197,868 \\
\$ 29,410,201 \\
\end{array}$ & $\begin{array}{c}1,560,583 \\
1,685,528 \\
\$ 277,478,239 \\
\end{array}$ & $\begin{array}{c}39.3 \\
-15.7 \\
7.7 \\
\end{array}$ & $\begin{array}{l}30.1 \\
11.7 \\
10.6 \\
\end{array}$ \\
\hline $\begin{array}{l}\text { Native American and Alaska Native: } \\
\text { Number of Firms } \\
\text { Employment } \\
\text { Sales }(\$ 000)\end{array}$ & $\begin{array}{c}77,483 \\
87,466 \\
\$ 8,700,015 \\
\end{array}$ & $\begin{array}{c}272,041 \\
495,427 \\
\$ 60,767,210 \\
\end{array}$ & $\begin{array}{l}44.6 \\
18.0 \\
28.8\end{array}$ & $\begin{array}{l}28.5 \\
17.7 \\
14.3 \\
\end{array}$ \\
\hline
\end{tabular}

Center for Women's Business Research (2004). Minority women-owned businesses in the United States, 2001: A fact sheet. Retrieved June 1, 2004, from www.womensbusinessresearch.org/minorityreports.html 
TABLE 2 - Factors That Contributed to the Success of Women Business Owners

\begin{tabular}{|c|c|c|c|c|c|c|c|c|c|}
\hline Factors & $\begin{array}{c}\text { Teo } \\
(\mathbf{1 9 9 6 )})\end{array}$ & $\begin{array}{c}\text { Deng, } \\
\text { Hassan } \\
\text { and } \\
\text { Jivan } \\
\text { (1995) }\end{array}$ & $\begin{array}{c}\text { Rashid } \\
(1996)\end{array}$ & $\begin{array}{c}\text { Hisrich } \\
\text { and } \\
\text { O'Brien } \\
(1981)\end{array}$ & $\begin{array}{l}\text { Kelly } \\
(\mathbf{1 9 8 5})\end{array}$ & $\begin{array}{c}\text { Leo- } \\
\text { Gosselin } \\
\text { And } \\
\text { Grise } \\
(1990) \\
\end{array}$ & $\begin{array}{c}\text { Bachemin } \\
(1989)\end{array}$ & $\begin{array}{c}\text { Woodward } \\
(\mathbf{1 9 8 8})\end{array}$ & $\begin{array}{l}\text { Kotter } \\
(1982) \\
\end{array}$ \\
\hline Countries & $\mathrm{S}$ & $\mathrm{A}$ & $\mathrm{S}$ & USA & $\mathrm{C}$ & $\mathrm{N}$ & USA & USA & USA \\
\hline Family Support & & $*$ & & $*$ & & & & & \\
\hline $\begin{array}{l}\text { Knowledge of Culture } \\
\text { and Language }\end{array}$ & & $*$ & & & & & & & \\
\hline Communication Skills & & & $*$ & & & & & $*$ & $*$ \\
\hline Human Relation Skills & & & $*$ & & & & & & \\
\hline Personal Qualities & $*$ & $*$ & & $*$ & & $*$ & & & \\
\hline $\begin{array}{l}\text { Knowledge of Product } \\
\text { and Service }\end{array}$ & $*$ & & & & & & & & \\
\hline $\begin{array}{l}\text { Quality of Product and } \\
\text { Service }\end{array}$ & $*$ & & & & & $*$ & & & \\
\hline Customer Loyalty & $*$ & & & & & & & & \\
\hline Quality of Personnel & $*$ & & & & & & & & \\
\hline $\begin{array}{l}\text { Availability of } \\
\text { Professional Services }\end{array}$ & $*$ & & & & $*$ & & & & \\
\hline $\begin{array}{l}\text { Technological } \\
\text { Advantage }\end{array}$ & $*$ & & & & & & & & \\
\hline $\begin{array}{l}\text { Availability of } \\
\text { Finance }\end{array}$ & $*$ & & & & & & & & \\
\hline $\begin{array}{l}\text { Presence of } \\
\text { Opportunities }\end{array}$ & & & & & & & $*$ & & \\
\hline Desire To Succeed & & & & $*$ & $*$ & & $*$ & & \\
\hline
\end{tabular}

$\mathrm{S}=$ Singapore, $\mathrm{C}=$ Canada, $\mathrm{N}=$ Netherlands, $\mathrm{A}=\mathrm{A}$ sia, USA=United States of America

Source: Maysami, R. and Goby, V. (1999). "Female Business Owners in Singapore and Elsewhere: A Review of Studies". Journal of Small Business Management, 37 (2), 96-105.

TABLE 3 - Miscellaneous Descriptive Statistics

\begin{tabular}{|l|c|c|c|c|c|}
\hline \multicolumn{1}{|c|}{ Race } & $\begin{array}{c}\text { Number of } \\
\text { Businesses }\end{array}$ & $\begin{array}{c}\text { Average } \\
\text { Sales Volume Per } \\
\text { Business (\$) }\end{array}$ & $\begin{array}{c}\text { Average } \\
\text { Employees Per } \\
\text { Business }\end{array}$ & $\begin{array}{c}\text { Average } \\
\text { Sales Per } \\
\text { Employee (\$) }\end{array}$ & $\begin{array}{c}\text { Average } \\
\text { Years In } \\
\text { Business }\end{array}$ \\
\hline Asians & $384(29.63 \%)$ & $1,374,561$ & 9 & 152,069 & 12.77 \\
\hline Blacks & $369(28.47 \%)$ & 737,679 & 11 & 69,263 & 12.82 \\
\hline Hispanics & $394(30.40 \%)$ & 669,951 & 7 & 100,289 & 12.58 \\
\hline Indians & $83(6.40 \%)$ & $1,022,980$ & 9 & 118,091 & 12.51 \\
\hline $\begin{array}{l}\text { Native } \\
\text { Americans }\end{array}$ & $66(5.09 \%)$ & $2,224,701$ & 27 & 82,212 & 13.64 \\
\hline Total & $\mathbf{1 , 2 9 6}$ & $\mathbf{8 0 7 . 6 5 1}$ & $\mathbf{8}$ & $\mathbf{9 8 , 9 6 5}$ & $\mathbf{1 2 . 9 0}$ \\
\hline
\end{tabular}


TABLE 4 - Industry Type By Race

\begin{tabular}{|l|c|c|c|c|c|c|}
\hline \multicolumn{1}{|c|}{ Industry Type } & Total & Asians & Blacks & Hispanics & Indians & $\begin{array}{c}\text { Native } \\
\text { Americans }\end{array}$ \\
\hline & 11 & 5 & 2 & 3 & 0 & 1 \\
Agriculture, Forestry, Fishing & $(0.85 \%)$ & $(1.3 \%)$ & $(0.05 \%)$ & $(0.07 \%)$ & $(0 \%)$ & $(1.51 \%)$ \\
\hline & 51 & 8 & 17 & 16 & 3 & 7 \\
Construction & $(3.94 \%)$ & $(2.08 \%)$ & $(4.60 \%)$ & $(4.06 \%)$ & $(3.61 \%)$ & $(10.60 \%)$ \\
\hline & 66 & 27 & 10 & 19 & 3 & 7 \\
Manufacturing & $(5.09 \%)$ & $(7.03 \%)$ & $(2.71 \%)$ & $(4.82 \%)$ & $(3.61 \%)$ & $(10.60 \%)$ \\
\hline Transportation Communications \& Public & 59 & 14 & 23 & 15 & 2 & 5 \\
Utilities & $(4.55 \%)$ & $(3.64 \%)$ & $(6.23 \%)$ & $(3.80 \%)$ & $(2.40 \%)$ & $(7.57 \%)$ \\
\hline & 111 & 54 & 23 & 21 & 9 & 4 \\
Wholesale Trade & $(8.56 \%)$ & $(14.06 \%)$ & $(6.23 \%)$ & $(5.32 \%)$ & $(10.84 \%)$ & $(6.06 \%)$ \\
\hline & 280 & 117 & 40 & 94 & 16 & 13 \\
Retail Trade & $(21.60 \%)$ & $(30.47 \%)$ & $(10.84 \%)$ & $(23.86 \%)$ & $(19.27 \%)$ & $(19.69 \%)$ \\
\hline & 59 & 17 & 19 & 17 & 5 & 1 \\
Finance, Insurance and Real Estate & $(4.55 \%)$ & $(4.42 \%)$ & $(5.15 \%)$ & $(4.31 \%)$ & $(6.02 \%)$ & $(1.51 \%)$ \\
\hline & 659 & 142 & 235 & 209 & 45 & 28 \\
Services & $(50.85 \%)$ & $(36.97 \%)$ & $(63.68 \%)$ & $(53.04 \%)$ & $(54.21 \%)$ & $(42.42 \%)$ \\
\hline Total & $\mathbf{1 2 9 6}$ & $\mathbf{3 8 4}$ & $\mathbf{3 6 9}$ & $\mathbf{3 9 4}$ & $\mathbf{8 3}$ & $\mathbf{6 6}$ \\
\hline
\end{tabular}

TABLE 5 - Geographic Location By Race

\begin{tabular}{|l|c|c|c|c|c|c|}
\hline $\begin{array}{l}\text { Geographic } \\
\text { Location }\end{array}$ & Total & Asians & Blacks & Hispanics & Indians & Native Americans \\
\hline Arizona & 31 & 8 & 6 & 10 & 1 & 6 \\
& $(2.39 \%)$ & $(2.08 \%)$ & $(1.62 \%)$ & $(2.53 \%)$ & $(1.20 \%)$ & $(9.09 \%)$ \\
\hline & 455 & 203 & 68 & 136 & 24 & 24 \\
California & $(35.11 \%)$ & $(52.86 \%)$ & $(18.42 \%)$ & $(34.51 \%)$ & $(28.91 \%)$ & $(36.36 \%)$ \\
\hline & 106 & 5 & 21 & 77 & 2 & 1 \\
Florida & $(8.18 \%)$ & $(1.30 \%)$ & $(5.69 \%)$ & $(19.54 \%)$ & $(2.40 \%)$ & $(1.51 \%)$ \\
\hline & 98 & 12 & 61 & 12 & 8 & 5 \\
Georgia & $(7.56 \%)$ & $(3.12 \%)$ & $(16.53 \%)$ & $(3.04 \%)$ & $(9.63 \%)$ & $(7.57 \%)$ \\
\hline & 133 & 31 & 49 & 36 & 12 & 5 \\
Illinois & $(10.26 \%)$ & $(8.07 \%)$ & $(13.27 \%)$ & $(9.13 \%)$ & $(14.45 \%)$ & $(7.57 \%)$ \\
\hline & 80 & 13 & 42 & 10 & 10 & 5 \\
Michigan & $(6.17 \%)$ & $(3.38 \%)$ & $(11.38 \%)$ & $(2.53 \%)$ & $(12.04 \%)$ & $(7.57 \%)$ \\
\hline & 174 & 62 & 44 & 49 & 15 & 4 \\
New York & $(13.43 \%)$ & $(16.14 \%)$ & $(11.92 \%)$ & $(12.43 \%)$ & $(18.07 \%)$ & $(6.06 \%)$ \\
\hline & 176 & 33 & 69 & 50 & 11 & 13 \\
Texas & $(13.58 \%)$ & $(8.59 \%)$ & $(18.69 \%)$ & $(12.69 \%)$ & $(13.25 \%)$ & $(19.69 \%)$ \\
\hline & 43 & 17 & 9 & 14 & 0 & 3 \\
Washington & $(3.32 \%)$ & $(4.42 \%)$ & $(2.43 \%)$ & $(3.55 \%)$ & $(0 \%)$ & $4.54 \%)$ \\
\hline Total & $\mathbf{1 2 9 6}$ & $\mathbf{3 8 4}$ & $\mathbf{3 6 9}$ & $\mathbf{3 9 4}$ & $\mathbf{8 3}$ & $\mathbf{6 6}$ \\
\hline
\end{tabular}

TABLE 6 - Chi-Square Relationships Of Race And Other Variables

\begin{tabular}{|l|c|c|}
\hline Relationships & Chi-Square Values & P Values \\
\hline Race and Geographic Location & 303.60 & 0.00 \\
\hline Race and Years in Business & 26.18 & 0.16 \\
\hline Race and Type of Business & 117.36 & 0.00 \\
\hline Race and Number of Employees & 15.76 & 0.47 \\
\hline Race and Sales Volume & 47.36 & 0.00 \\
\hline
\end{tabular}


TABLE 7 - Chi-Square Relationships Of Sales Volume And Other Variables

\begin{tabular}{|l|c|c|}
\hline Relationships & Chi-Square Values & P Values \\
\hline Sales Volume Geographic Location & 91.99 & 0.01 \\
\hline Sales Volume and Years in Business & 58.07 & 0.03 \\
\hline Sales Volume and Type of Business & 313.15 & 0.00 \\
\hline Sales Volume and Number of Employees & 1473.45 & 0.00 \\
\hline Sales Volume and Race & 47.36 & 0.00 \\
\hline
\end{tabular}

\section{REGRESSION ANALYSES}

The first regression analysis used sales volume as the dependent variable and number of employees, years in business, type of business and race as independent variables. It should be noted that the default variable for the race category is "American Indian" and the default variable for the type of industry category is "services". The results are presented in Table 8 and indicate that the independent variables predict approximately $40.66 \%$ of the dependent variable. This can be restated to mean that the $\mathrm{R}$-square value for the dependent variable is only being accounted for by $40.66 \%$ of the independent variables.

Table 9 again looks at another regression analysis and again sales volume is the dependent variable. However, in this instance, the race variable is held constant and the number of years in business, number of employees and type of business are being used as independent variables. With race held constant, the R-square value drops to $40.49 \%$, indicating that the independent variables can now explain $40.49 \%$ of the dependent variable.

TABLE 8 - Regression Results: Sales Volume (Dependent Variable) And Years In Business, Number Of Employees, Type Of Business And Race (Independent Variables)

\begin{tabular}{|l|c|c|}
\hline Variables & Beta Coefficients & P Values \\
\hline Intercept & -285321.51 & 0.639 \\
\hline Number of Employees & 84155.30 & $1.89 \mathrm{E}$ \\
\hline Years in Business & -5529.08 & 0.695 \\
\hline Asian & 553236.32 & 0.363 \\
\hline Black & -80410.85 & 0.895 \\
\hline Hispanic & 255390.38 & 0.673 \\
\hline Indian & 306200.93 & 0.683 \\
\hline Agriculture, Forestry, Fishing & -114789.12 & 0.933 \\
\hline Construction & 895155.60 & 0.171 \\
\hline Manufacturing & 267937.71 & 0.648 \\
\hline Manufacturing, Transportation, & 1157792.64 & 0.062 \\
\hline Communications, Public Utilities & & \\
\hline Wholesale Trade & 2581165.39 & $4.63 \mathrm{E}$ \\
\hline Retail Trade & -64740.47 & 0.845 \\
\hline Finance, Insurance, Real Estate & 64758.93 & 0.916 \\
\hline
\end{tabular}

R-Square $=0.4066, \mathrm{~N}=1276$ 
TABLE 9 - Regression Results: Sales Volume (Dependent Variable) And Years In Business, Number Of Employees, Type Of Business (Independent Variables). Race Held Constant.

\begin{tabular}{|l|c|c|}
\hline Variables & Beta Coefficients & P Values \\
\hline Intercept & -89060.02 & 0.720 \\
\hline Number of Employees & 83956.66 & $5.465 \mathrm{E}$ \\
\hline Years in Business & -5680.72 & 0.687 \\
\hline Agriculture, Forestry, Fishing & -1206.28 & 0.999 \\
\hline Construction & 861816.19 & 0.186 \\
\hline Manufacturing & 381615.44 & 0.512 \\
\hline $\begin{array}{l}\text { Manufacturing, Transportation, } \\
\text { Communications, Public Utilities }\end{array}$ & 1136742.48 & 0.066 \\
\hline Wholesale Trade & 2715027.30 & $5.109 \mathrm{E}$ \\
\hline Retail Trade & 64044.22 & 0.843 \\
\hline Finance, Insurance, Real Estate & 110258.37 & 0.857 \\
\hline
\end{tabular}

R-Square $=0.4049, \mathrm{~N}=1276$

\section{DISCUSSION AND CONCLUSION}

The last several years has witnessed a number of articles focused on the growing interest on women entrepreneurs. Surprisingly however, few of that research have examined minority women entrepreneurs exclusive of outside comparisons and internally across various minority racial lines. This paper focused on the impact of geographic location, industry type, number of employees and number of years in business on the economic success of minority women entrepreneurs. The findings were mixed. On the one hand, there was a relatively small $\mathrm{R}$ square value when looking at the regression analysis. On the other hand, the value $(0.4066)$ could be seen as relatively large, considering only four variables were used in the regression analysis. When race was held constant, there was very little change in the R-square value. Moreover, there were significant relationships found between race and the following: geographic location, type of business and sales volume and between sales volume and the following: geographic location, years in business, type of business and number of employees.

These findings can serve as precursors to more intricate regression analyses that can include, in addition to the significantly related correlation factors, other factors that would be expected to provide significant results.

\section{REFERENCES}

1. Bates, Timothy (1997). Race, Self-Employment, and Upward Mobility: An Illusive American Dream. Baltimore, MD: Johns Hopkins University Press.

2. Becker, P. and Moen, P. (1999). "Scaling Back: Dual-Earner Couples' Work Family Strategies". Journal of Marriage and Family, 61 (4), 995-1007.

3. Birch, David L. (1987). Job Creation in America: How Our Smallest Companies Put the Most People to Work. New York: The Free Press.

4. $\quad$ Brimmer, Andrew, and Terrell, H. (1971). "The Economic Potential of Black Capitalism." Public Policy 14: 289-308.

5. Center for Women's Business Research (2004). "Minority women-owned businesses in the United States", 2001: A fact sheet. Retrieved June 1, 2004, from www.womensbusinessresearch.org/minorityreports.html

6. Dun and Bradstreet (2003). "Direct Sales and Marketing Catalog: To Help You Grow Your Business".

7. Edwards, L. and Field-Hendrey, E. (1996). "Home-based workers: Data from the 1990 Census of Population". Monthly Labor Review, 119 (11), 26-34.

8. Ehlers, T. and Main, K. (1998). "Women and the false promise of microenterprise". Gender and Society, Vol. 12 (4), 424-440.

9. Furry, M. 1992. "Home-based work in Nine States: An empirical Study". Southeastern Regional Association of Family Conference Proceedings. 
10. Haddleston-Mattai, B. (1995). "The black female academician and the 'superwoman syndrome"”. Race, Gender and Class, 3, 49-64.

11. Inman, K. (2000). Women's Resources in Business Start-up: A Study of Black and White Women Entrepreneurs. New York: Garland Publishing.

12. Light, Ivan, and Steven J. Gold. (2000). Ethnic Economies. Orlando, FL: Academic Press.

13. Loscocco, K. and Leicht, K. (1993). "Gender, work-family linkages and economic success among small business owners". Journal of Marriage and Family, 55, 875-887.

14. Loscocco, K. and Robinson, J. (1991). "Barriers to women's small business success in the United States". Gender and Society, 5, 4, 511-532.

15. Loscocco K., Robinson J., Hall R.H., Allen J.K. (1991). "Gender and small business success: An inquiry into women's relative disadvantage". Social Forces 70(1), 65-83.

16. Maysami, R. and Goby, V. (1999). "Female Business owners in Singapore and Elsewhere: A Review of Studies". Journal of Small Business Management, 37 (2), 96-105.

17. Moore, D. and Buttner, H. (1997). Women Entrepreneurs: Moving Beyond the Glass Ceiling. Thousand Oaks, California: Sage Publication.

18. Olson, P. 1997. "Are the floors less sticky at home? Pay-equity in home-based work". Consumer Interests Annual, 43, 239-243.

19. Priesnitz, W. (1989). "Running a business out of your home". Women and Environments, 11, 4-8.

20. Sanders, Jimy M. and Nee, V. (1987). "Limits of Ethnic Solidarity in the Enclave Economy." American Sociological Review 52: 745-767.

21. Smith, Shelley A. and Tienda, M. (1988). "The Doubly Disadvantaged: Women of Color in the U.S. Labor Force." Pp. 61-80 in Women Working: Theories and Facts in Perspective, edited by Ann Helton Stromberg and Shirley Harkness. Mountain View, CA: Mayfield Publishing Company.

22. Smith-Hunter, A. E. (2003). Diversity and Entrepreneurship: Analyzing Successful Women Entrepreneurs. Lanham, MD: University Press of America.

23. Wilson, Kenneth L. and Portes, A. (1980). "Immigrant Enclaves: An Analysis of the Labor Market Experiences of Cubans in Miami." American Journal of Sociology 86: 295-319.

24. Zhou, Min, and Logan, J. (1989). "Returns on Human Capital in Ethnic Enclaves: New York City's Chinatown.” American Sociological Review 54: 809-820. 


\section{$\underline{\text { Notes }}$}

